\title{
Conventionality Standards for Children in Conflict Zones: Colombian Case study
}

\author{
Received: November 22 2018 - Approved: December $3^{\text {rd }} 2018$
}

https://doi.org/10.22395/ojum.v17n35a7

\author{
Luiz Guilherme Arcaro Conci* \\ Konstantin Gerber ${ }^{* * *}$
}

\begin{abstract}
The main objective of this paper is to identify the multilevel perspective of human rights protection for children in armed conflicts. For that, the pro persona or pro homine principle may be applied. It consists of an interpretative instrument provided by art. 29 of the American Convention of Human Rights and by art. 41 of the Convention on the Rights of the Child. The present analysis tackles distinct levels of protection, both at an international level and at the national level in Colombia and uses the pro homine principle to resolve eventual conflicts between the International Human Rights Law and domestic law.

Keywords: children rights; Colombia's armed conflict; pro persona principle; conventionality block.
\end{abstract}

The portuguese version of this article will be published by VII Fórum dos Grupos de Pesquisa em Direito Constitucional e Teoria do Direito.

A versão em português deste artigo será publicada no VII Foro de los Grupos de Investigación en Derecho Constitucional y Teoría del Derecho (VII Fórum dos Grupos de Pesquisa em Direito Constitucional e Teoria do Direito).

** Professor of Constitutional Law and Political Science and Theory of State at the Pontifical Catholic University of São Paulo (PUC-SP), responsible for the coordination of the Master in Constitutional Law and Professor at the Master in Global Governance and Formulation of International Public Policies. Full Professor of Theory of State of the Law School at the Faculty of Law of São Bernardo do Campo (FDSBC). Doctoral and master's degree in Constitutional Law (PUC-SP), with post-doctoral studies at the Universidad Complutense de Madrid (2013-2014). Visiting Professor at the University of Buenos Aires (2011-2014), University of Bologna (2016) and University of Messina (2019). Leader of the Fundamental Rights Research Group (PUC-SP). E-mail: Igaconci@hotmail.com Orcid: https://orcid.org/0000-0001-8502-8990

Professor de Direito Constitucional, Ciência Política e Teoria do Estado na Pontifícia Universidade Católica de São Paulo (PUC-SP), coordenador do Mestrado em Direito Constitucional e Professor do Mestrado em Governança Global e Formulação de Políticas Públicas Internacionais. Professor titular de Teoria do Estado da Faculdade de Direito em São Bernardo do Campo (FDSBC). Tem doutorado e mestrado em Direito Constitucional (PUC-SP) e estudos de pós-doutorado da Universidade Complutense de Madrid (2013-2014). Professor visitante na Universidade de Buenos Aires (2011-2014), Universidade de Bolonha (2016) e Messina (2019). Líder do Grupo de Pesquisa em Direitos Fundamentais (PUC-SP). E-mail: lgaconci@hotmail.com

... Consultant attorney in São Paulo. Master's degree and currently obtaining doctoral degree in Philosophy of Law at PUC-SP. Researcher at the Fundamental Rights Research Group. Guest Professor in the courses of Constitutional Law and International Law of Human Rights. E-mail: k.gerber@uol.com.br Orcid: https://orcid.org/0000-0002-1028-6810

Advogado consultor em São Paulo. Mestre e doutorando em Filosofia do Direito na PUC-SP. Pesquisador do Grupo de Pesquisa em Direitos Fundamentais. Professor convidado nos cursos de Direito Constitucional e Direito Internacional dos Direitos Humanos. E-mail: k.gerber@uol.com.br 


\title{
Estándares de convencionalismo para niños en zonas de conflicto: estudio de caso en Colombia
}

\begin{abstract}
RESUMEN
El objetivo principal de este documento es identificar la perspectiva multinivel de la protección de los derechos humanos para niños en los conflictos armados. Para eso, se puede aplicar el principio pro persona o pro homine, un instrumento interpretativo que proporciona el art. 29 de la Convención Americana de Derechos Humanos y el art. 41 de la Convención sobre los Derechos del Niño. El presente análisis aborda distintos niveles de protección, tanto a nivel internacional como a nivel nacional en Colombia y utiliza el principio pro homine para resolver eventuales conflictos entre el derecho internacional de los derechos humanos y la legislación nacional.

Palabras clave: derechos de los niños; conflicto armado colombiano; principio pro persona; bloque de convencionalidad.
\end{abstract}

\section{Parâmetros de convencionalidade para crianças em zonas de conflito: estudo do caso colombiano}

\section{RESUMO}

O objetivo principal deste trabalho é identificar a perspectiva multinível da proteção de direitos humanos para crianças em conflitos armados. O princípio pro persona consiste em um instrumento interpretativo fornecido pelo art. 29 da Convenção Americana sobre Direitos Humanos e pelo art. 41 da Convenção sobre os Direitos da Criança. A análise abrange diferentes níveis de proteção, tanto no nível internacional quanto no nível nacional colombiano e utiliza o principio pro persona para solucionar conflitos entre o direito internacional dos direitos humanos e o direito doméstico.

Palavras-chave: direitos da criança; Colômbia conflito armado; princípio pro persona; bloco convencionalidade. 


\section{INTRODUCTION}

This paper focuses on the protection of children in cases of armed conflicts and the relation between distinct levels of protection and how to implement them, both at the international level and at Colombia's national level. The territory has suffered from an armed conflict for more than fifty years. There are countless juridical matters regarding the juridical status of the children involved, or of those who were recruited when they were children, which still need to be solved. Thus, the search for these binding rules comprehends legal standards derived from the global system headquartered at the United Nations; the Inter-American Human Rights System and the domestic legal system.

This multilevel setting constitutes a block of binding juridical rules formed by treaties and other international instruments, as well as by the interpretation given by the competent organs, composing the socalled "block of conventionality", which must be read alongside the Constitution, laws, peace agreements, jurisprudence etc.

\section{CHILDREN IN CONFLICT ZONES: GLOBAL SYSTEM FOR THE PROTECTION OF HUMAN RIGHTS}

The first article of the UN Convention on the Rights of the Child, approved on November $2^{\text {nd }}$ of 1989 , defines the age of 18 as the end of childhood, but does not establish when it begins (Brett, 2012). The person aged less than 18 years is considered a child, unless the law determines otherwise.

The special protection for children had already been mentioned in the Geneva Convention of 1949 (for protection of war victims) and its additional protocols (international and non-international armed conflicts) and was specifically discussed in the UN Convention on the Rights of the Child. Those protocols established that the minimal age to be recruited is 15 years and the States Parties shall endeavour to give priority to those who are oldest (art. 77.2 of the Additional Protocol I and art. $4.3 \mathrm{c}$ ) of the Additional Protocol II).

"International armed conflict" has a couple of meanings, as in the cases of declared wars among the States, for example. Still, there are other forms of armed conflicts: when the state of war is not recognized by one of the States or when there is a fight against colonial domination, foreign occupation or racist regimens (right to the free determination of peoples, art. 1.4, Additional Protocol I).

Thus, in a non-international armed conflict, the art. 1 of the Additional Protocol II, which develops and complements the article 3, mutual to the Geneva Conventions of August 12 $2^{\text {th }}$ of 1949, may be applied to every armed conflict which is not covered by article 1 of the Additional Protocol I to the Geneva Conventions of August $12^{\text {th }}$ of 1949 , regarding the protection of victims of international armed conflicts. It must also be taken into account that the Additional Protocol 
II is not applied in cases of internal riots, isolated and occasional acts of violence, as well as other similar cases, which are not considered armed conflicts. The latter concerns the conflicts among the State and armed groups, or among armed groups themselves. An armed conflict, is, thus, a de facto situation, which may comprehend periods of truce and hostility (Aliverti, 2004). It is a situation where there is use of armed force among States, among a State and an organized group, or among armed organized groups within a State (Nemer Cladeira \& Soares, 2009).

As previously mentioned, the States and armed groups cannot recruit individuals younger than 15 years old, nor can they put these persons to participate directly in the acts of war. The indirect participation, though, such as transmitting information or carrying guns in the international armed conflicts is not forbidden (Aliverti, 2004). On the other side, regarding the non-international armed conflicts, both the direct and the indirect participation of young under 15 , such as gathering information, transmitting orders, carrying ammunition, supplies and practicing acts of sabotage, are forbidden (Dutli, 2003).

Recruiting and using children under 15 in the active participation of acts of war on international or non-international armed conflicts is considered a war crime (arts. 8.2 b), XXVI; 8.2 e), VII of the Rome Statute), whether practiced by States or groups. "Active participation" includes directly aiding in combat and military activities, such as patrol, espionage and sabotage, which includes the use of children as baits and messengers (Martuscelli, 2006, p. 12).

The forced labor of children (up to 18 years old) is one of the worst forms of child labor (art. 3, a), 182 Convention of the International Organization of Labor). The art. $38^{1}$, first paragraph of the Convention on the Rights of the Child refers to the Geneva Conventions; thus the importance to enforce the art. 4.3 c) of the Additional Protocol II, since it forbids children under 15 to participate, directly and indirectly in the hostilities (Duttli, 2003). The art. 39 of the UN Convention establishes the duty of the States to provide physical and psychological rehabilitation and the social reintegration as well, of children who were victimized by armed conflicts.

After discussions on the Committee on the Rights of the Child, an Optional Protocol was proposed, regarding the involvement of children in armed conflicts. Also, a study on the impact of those conflicts was requested by the General Assembly

Article 38 affirms the following: "1. States Parties undertake to respect and to ensure respect for rules of international humanitarian law applicable to them in armed conflicts which are relevant to the child. 2. States Parties shall take all feasible measures to ensure that persons who have not attained the age of fifteen years do not take a direct part in hostilities. 3. States Parties shall refrain from recruiting any person who has not attained the age of fifteen years into their armed forces. In recruiting among those persons who have attained the age of fifteen years but who have not attained the age of eighteen years, States Parties shall endeavour to give priority to those who are oldest. 4. In accordance with their obligations under international humanitarian law to protect the civilian population in armed conflicts, States Parties shall take all feasible measures to ensure protection and care of children who are affected by an armed conflict (UN, 1989). 
of the UN (art. 45, c), Convention of the Rights of the Child, of the United Nations) (Brett, 2012).

This study, known as the "Machel Study", has contributed to the creation of a special rapporteur of the UN Secretariat on children in armed conflicts and the edition of specific resolutions by the UN Security Council: Resolution 1539 from April 22 $2^{\text {nd }}$ of 2004 and 1612 from July 26 th of 2005 (Brett, 2012). After that, in 2007, ten years after the UNICEF statement of the Cape Town principles (1997), the Paris Principles concerning children involved in armed conflicts were established.

The Optional Protocol to the Convention on the Rights of the Child on the involvement of children in armed conflicts establishes the States' duty of not recruiting the underaged compulsorily. It sets requirements for the voluntary enlistment from the age of 15 , such as to raise the minimum age (arts. 2 and 3).

Although mandatory for the States Parties, according to the art. 4, the armed groups which do not belong to the armed forces of the State must not recruit the under aged for hostilities, what makes the State responsible for the acts of individuals. The States must do everything to avoid such recruitment, including criminalizing such practices.

On the other hand, the child soldiers benefit from the general protection of art. 75 of Protocol I, which establishes the fundamental guarantees for prisoners of war (Dutli, 2003) but there isn't the same level of protection when we talk about it not being the case of a non-international conflict, given the absence of the prisoner of war status. The ones who are captured in a non-international armed conflict, on the other hand, are protected by the art. 3 of the Geneva Convention of 1949 for people who do not or no longer participate in the acts of violence. The art. 4 , paragraph $3^{\text {rd }}$ also provides other rights such as education and reunion with their families as well as the prohibition of the death penalty under art. 6, paragraph 6 (Dutli, 2003).

\section{THE PROTECTION OF CHILDREN BY THE INTER- AMERICAN HUMAN RIGHTS SYSTEM}

According to the art. 19 of the American Convention on Human Rights ("ACHR"), every child has the right to the measures of protection required by his/her condition as a minor on the part of his family, society, and the State (Brasil, 1992). These rights are better described in the art. 16 of the Additional Protocol of San Salvador: the right to grow under the protection and responsibility of his parents; save in exceptional, judicially-recognized circumstances, a child of young age ought not to be separated from his mother, and the right to free and compulsory education, at least in the elementary phase.

The protection of the children's rights in the Inter-American System ${ }^{2}$ is really important. It is not possible to suspend

The Organization of American States has edited, in 2000, a Resolution on Children in Armed Conflicts. 
children's rights and their imperative judicial guarantees, not even in the situations which allow the suspension of rights, such as the one provided by art. 27 of the American Court of Human Rights (ACHR) (2015).

The Inter-American Court of Human Rights (IACHR), in its jurisprudence, has also been building reference to children through the Inter-American block of conventionality. The Court understands that the application of the Geneva Conventions is indirect, given the fact that it is allowed to interpret clauses of the American Convention through other international treaties, according to the pro persona clause of the art. 29 of the ACHR. Instead, the Inter-American Commission understands that the direct application of other treaties is possible (Nemer Caldeira $\varepsilon$ Soares, 2009).

The idea of a block of conventionality requires attention to other cases on this subject matter. The IACHR has specifically discussed children rights in some cases:

a) In the exercise of its consultative jurisdiction, a) OC-17/2002, regarding the juridical condition and the human rights of the child; and b) OC-18/2003, regarding the juridical conditions and the rights of the undocumented child; and

b) In the exercise of its contentious jurisdiction, in other cases, such as the Villagrán-Morales and others v. Guatemala (1999); Yean and Bosico v. Dominican Republic (2005); Servellón-García and others v. Honduras (2006); González and others v. Mexico (2009); Contreras and others v. El Salvador (2011).

In the case Vargas Areco v. Paraguay, child recruitment was deeply discussed. Gerardo Vargas Areco, was a child recruited by the military service at the age of 15 and was executed by a sub official. The Court highlighted that the international law has special rules to protect the physical and psychological integrity of children who are serving the military service (Ibáñez Rivas, 2010).

Another important reference on this subject matter is given by paragraph 209 of the case "Ituango Massacre", when the Court found ground on the International humanitarian law to discuss the displaced (art. 17 of the Protocol II of the Geneva Convention), since forced displacement is forbidden. The State must, at least, ensure lodging, health, safety and food in cases of displacement by virtue of absolutely necessary military reasons (IACHR, 2006).

In another Colombian case of massacre committed by paramilitary organizations judged by the IACHR (the "Maripirán Massacre"), the Court expressed that the rules of International humanitarian law had been declared as ius cogens by the Colombian Constitutional Court, on paragraphs 114 and 115: 
[...] with regard to establishment of the international responsibility of the State in the instant case, the Court cannot set aside the existence of general and special duties of the State to protect the civilian population, derived from International Humanitarian Law, specifically Article 3 common of the August 12, 1949 Geneva Agreements and the provisions of the additional Protocol to the Geneva Agreements regarding protection of the victims of noninternational armed conflicts (Protocol II). Due respect for the individuals protected entails passive obligations (not to kill, not to violate physical safety, etc.), while the protection due entails positive obligations to impede violations against said persons by third parties. Carrying out said obligations is significant in the instant case, insofar as the massacre was committed in a situation in which civilians were unprotected in a non-international domestic armed conflict.[...]

The obligations derived from said international provisions must be taken into account, according to Article 29.b) of the Convention, because those who are protected by said treaty do not, for that reason, lose the rights they have pursuant to the legislation of the State under whose jurisdiction they are; instead, those rights complement each other or become integrated to specify their scope or their content. While it is clear that this Court cannot attribute international responsibility under International Humanitarian Law, as such, said provisions are useful to interpret the Convention, in the process of establishing the responsibility of the State and other aspects of the violations alleged in the instant case. These provisions were in force for Colombia at the time of the facts, as international treaty agreements to which the State is a party, and as domestic law, and the Constitutional Court of Colombia has declared them to be jus cogens provisions, which are part of the Colombian 'constitutional block' and are mandatory for the States and for all armed State and non-State actors involved in an armed conflict (IACHR, 2005, pp. 90-91).

On paragraph 153, regarding the content of art. 29 of the Inter-American Convention, it considered that the clauses of the Convention regarding the rights of the child (arts. 6, 37, 38 and 39) and the Protocol II of the Geneva Conventions would constitute an international corpus juris for child protection (IACHR, 2005). The Court understood that there had been violations of the art. 19 of the InterAmerican Convention, along with arts. 4.1, 5.1, 1.1 (fatal child victims) and with 22.1, 4.1 and 1.1 (displaced child victims).

\section{THE PRO PERSONA PRINCIPLE APPLIED TO CHILDREN}

The Universal Declaration of Human Rights comprehends general principles destined to protect human dignity. The pro persona principle, in short, consists of an interpretative instrument developed by the legal doctrine and also established in the treaties. The main objective is to always seek the best protection for hu- 
man dignity. That means that if there is more than one rule applicable to a case, the one which preserves the right in the widest or in a less restrictive possible way, should prevail. That is the understanding of Mónica Pinto on the subject matter. The pro persona principle is a criterion that gives extensive interpretation to offer a broader protection and, inversely, most restricted interpretation when a rule establishes permanent restrictions or extraordinary suspension on the exercise of human rights (Pinto, 1997, p. 163).

Characterized as the maximal central hermeneutics for the interpretation of human rights, the pro persona principle broadens the exercise of every right, considers that the juridical rules do not exclude, but instead, complete each other. The application of this principle must be made in a contingent way, that is, in light of a conflict among two juridical rules, instead of the chronological, literal, hierarchical or specialty criteria, there must be a concurrent analysis, from which the interpretation that best protects human dignity will arise.

Although this concept comes from the legal doctrine, the pro persona principle is provided by several juridical instruments which are part of the International Human Rights Law. The principle is mentioned on art. 41 of the Convention on the Rights of the Child "Nothing in the present Convention shall affect any provisions which are more conducive to the realization of the rights of the child", and in the art. 29, b), of the American Convention on Human
Rights (Brasil, 1992), which states that no provision of the Convention shall be interpreted as "restricting the enjoyment or exercise of any right or freedom recognized by virtue of the laws of any State Party or by virtue of another convention to which one of the said states is a party". Also, the Vienna Convention, on art. 27, establishes that "A party may not invoke the provisions of its internal law as justification for its failure to perform a treaty" (Brasil, 2009).

Therefore, both treaties and the national law may be applied, as long as they are more conducive. It means that the hierarchy is unimportant for conventionality control. Whenever there is a collision between the treaties and the internal law, an unconventionality analysis must take place in order to check which normative instrument, national or international, is more protective or less restrictive to the involved human right (pro persona principle). If the conclusion is that the international treaty accomplishes the pro persona principle, there is an unconventionality situation. On the other hand, if the internal acts are more protective or less restrictive, the construction must be according to the American Convention on Human Rights (minimum standards) and the jurisprudence of the Inter-American Court.

\section{COLOMBIA: A CASE STUDY}

Discussing the origins of the Colombian armed conflict, which is necessary for juridical comparisons, requires stating 
multiple variables, which range from the absence of authority of the State for violence control, territory dominance, taxation or justice, recurring political violence since the Thousand Day's War, that occurred at the end of the $19^{\text {th }}$ Century; to the assassination of a presidency candidate, which created lots of conflicts, in 1949 and 1958; and the revolutionary violence with insurgent organizations that started in the 1960's. In fact, apart from a specific occurrence during the 1950's, there have not been dictatorships.

The variety of positions:

a) 1926 Supreme Court decision on property title requirement (Gallego, 2009)

b) The absence of State authority for violence control

c) The struggle for territory dominance, taxation or justice;

d) Since 1946, violence against the agrarian reform (Guillén, 2006);

e) Recurring political violence, as the murder of presidential candidate Jorge Eliécer Gaitán in 1948;

f) Law 48 of 1968 (which legalized the paramilitary army or autodefensas).

The scenario of violence is complex: paramilitaries, private justice groups, militias, youth gangs, organized delinquency, drug trafficking armies and State security forces, with migration between them. The war against the guerrilla has been done with mercenary practices in the context of transitory alliances, with settlement and depopulation of territories (Uribe de Hincapié, 1997).

As accepted by Trejos Rosero (2013), the absence of a State enabled the occupation by private forces. The guerrillas took the place of the State to provide justice and goods, only supplied by the State in the urban centers (Trejos Rosero, 2013). In this scenario, since the 1980's, the paramilitares appeared to fight against the guerrillas financed by drug cartels, land owners, etc. (Valentine, 2003).

The estimation is that these armed conflicts caused the forced internal displacement of three million people, and the State, in this scenario, adopts a form of a State of Exception, in which the constitutional boundaries are fragile to control the public instruments against fundamental rights (Peco Yuste $\mathcal{E}$ Peral Fernández, 2005).

The expression "armed conflict" has received significant attention by the Colombian Constitutional Court:

$$
\begin{aligned}
& \text { [...] far from being understood un- } \\
& \text { der restrictive optics, in the limits } \\
& \text { of strictly military confrontations } \\
& \text { or concerning a specific group of } \\
& \text { actors, it has been interpreted in } \\
& \text { a broad meaning, which includes } \\
& \text { all of the complexity and factual } \\
& \text { and historical evolution of the } \\
& \text { Colombian armed conflict (2012). }
\end{aligned}
$$

Note that Colombia has been condemned in eleven paramilitary violence cases by 
the IACHR (Hassan, 2013). The Constitution of 1991 sets the rights of the child as fundamental. There are duties for the family, society and the State to protect and ensure their full development. In article 44, the Colombian Constitution establishes the right of the child to life, social security, balanced food, to have a family and not be separated from it, education, culture, recreation and freedom of speech.

The UN Convention on the Rights of the Child was approved by Colombia through Law 12 of 1991. A reservation was made, however, on items 2 and 3. Military recruitment is only allowed from age 18 .

Child soldiers in Colombia were subject of the Resolution 1612 of 2005 of the UN Security Council. Moreover, the recruitment of underaged children is a crime in Colombia (art. 162, Criminal Code), and since the 1990's, the State has created a program to prevent recruitment of children and advise the demobilization (Martuscelli, 2006) through the Reintegration Agency.

Before the Congress approval of the legislative act for the peace (Acto Legislativo n. ${ }^{\circ}$ 1 de 2017) other laws had been approved in Colombia regarding this theme, such as Law 27 of $1997^{3}$, Law 975 of $2005^{4}$ and Law 1448 of 2011.

Article 1 establishes that "for legal purposes, the definition of 'age' concerns those who have surpassed 18 years of age".

4 Art. 13 states that the recruitment of underaged is forbidden, even if voluntarily, which had already been prohibited by Law 548 of 1999, art. 2 .
The Law 1098 of 2006, article 20, states that children and teenagers shall be protected from wars and internal armed conflicts, from the recruitment and utilization by outlaw organized armed groups and refers the International Labor Organization (ILO) Convention n. ${ }^{\circ}$ 182, which considers these as prohibited forms of labor.

The Rome Statute has been in force since November $1^{\text {st }}$ of 2002. The International Criminal Court has been examining this matter in Colombia for 16 years, which opens the door for a profound investigation of crimes against humanity (Isa, 2014): (i) proceedings related to killings and enforced disappearances, commonly known as "false positives" cases; (ii) proceedings related to forced displacement; (iii) proceedings related to sexual crimes; and (iv) national proceedings related to the promotion and expansion of paramilitary groups.

Also, Law 704 of 2001 approved the ILO Convention n. ${ }^{\circ} 182$, which prohibits the worst forms of child labor and Law 833 of 2003 Law approved the Optional Protocol to the Convention on the Rights of the Child on May $25^{\text {th }}$ of 2000. Concerning this protocol, the Constitutional Court stated (C-172/04, item 4.3) that there is a collision between the juridical instruments. Since the Protocol is more protective, it must prevail, according to the pro persona principle:

Aims at providing higher protection and guarantees to children and teenagers, since it does not 
allow their direct participation in the conflicts, and imposes to the States Parties, which have been compromised with the international community, the duty to cooperate on the enforcement of its rules. [...] There is an identity of purposes with the rules established by the Constitution, the international instruments and the existing standards of lower hierarchy regarding this subject.

On the other hand, and in light of the provisions of the Convention on the Rights of the Child regarding recruitment, the Protocol is considered to be more protective to children and teenagers facing armed conflicts.

The Constitutional Court of Colombia also decided relevant cases, like:

a) C-203 2005: The issue of the criminal trial of child combatants (including demobilization administrative procedures) must be geared towards social readaptation, rehabilitative, educational and protective objectives;

b) C-253A 2012: Children recruited by these outlaw organizations are victims according to international standards;

c) C-781 2012: Defines the terms "victims" and "armed conflicts".

In the current peace process with the Fuerzas Armadas Revolucionarias de Colombia (FARC-EP), a priority has been set: the demobilization and reintegration of child soldiers, which will depend not only on a constant budget for efficient policies, but also on a special peace jurisdiction ${ }^{5}$, which must take into account the peculiar conditions for the development of children, including for responsibility purposes. The challenge of demobilization of all child soldiers will remain an issue until the peace agreement reaches other armed groups, beyond the FARC-EP. The Final Agreement for Ending the Conflict and Constructing a Stable and Lasting Peace, signed November $24^{\text {th }}$ of 2016, in its item 3.2.25 stated, regarding the reincorporation of minors who left the FARC-EP campsites, that:
[...] These minors will be ac- corded all the rights, benefits and allowances established for the victims of the conflict as well as those deriving from their process of reincorporation in the terms contemplated in this Final Agreement and priority will be given to family reunification wherever possible, and to final placement in homes in their original communities or others of a similar nature, whilst at all times taking into account the best interests of the child. (...).

Also, in 2016 the National Council for Reincorporation was created (Decree 2027). It sets the activities and the monitoring of the FARC-EP members' reincorporation process to the juridical life. It also has the duty of discussing special measures of care and protection for children and teenagers who left or fled the camps.

One may ask if the special jurisdiction be consistent with the precedents of the Colombian Constitutional Court, especially Judgment C-203 of 2005? 


\section{CONCLUSION}

The international and domestic juridical standards, whether soft or hard law, may help building a less excluding and brutal society which affects the most fragile of its members: children victimized by an endless conflict.

The pro persona principle can thus be an important instrument for the construction of these normative standards which derive from several levels (multilevel constitutionalism).

\section{REFERENCES}

Aliverti, A. (2004). La protección de los niños en los conflictos armados bajo el derecho internacional humanitario. Lecciones y Ensaios (80), 441-461.

Nemer Caldeira, B. L. and Soares, Campos de Oliveira, L. (2009). A inter-relação entre o direito internacional dos direitos humanos e o direito internacional humanitário na perspectiva universal e interamericana. Anuario de Derecho Constitucional Latinoamericano, XV, 603-619.

Brasil (1992). Convenção Americana de direitos humanos. Decreto 678 de 06 de novembro de 1992. Retrieved from http://www.planalto.gov.br/ ccivil_03/decreto/D0678.htm

Brasil (2009). Convenção de Viena sobre o direito dos tratados. Decreto 7.030 de 14 de dezembro de 2009. Retrieved from http://www.planalto.gov.br/ ccivil 03/ Ato2007-2010/2009/Decreto/ D7030.htm

Brett, R. (2012). Rights of the child. En C. Krause y M. Scheinin (Ed.), International protection of human rights: A textbook (pp. 243-264) Turku, Abo, Finland: Abo Akademi University Institute of Human Rights.
Colombia (2016). Final agreement to end the armed conflict and build a stable and lasting peace. Retrieved from http://especiales.presidencia. gov.co/Documents/20170620-dejacionarmas/acuerdos/acuerdo-final-ingles.pdf

Colombia Constitutional Court (2005). C-203 Retrieved from http://www.corteconstitucional. gov.co/relatoria/2005/c-203-05.htm

Colombia Constitutional Court (2012a). C-781. Retrieved from http://www.corteconstitucional. gov.co/relatoria/2012/C-781-12.htm

Colombia Constitutional Court (2012b). C-253A Retrieved from http://www.corteconstitucional.gov.co/relatoria/2012/C-253A-12.htm

Colombia Constitutional Court (2004). C-172 Retrieved from http://www.corteconstitucional. gov.co/relatoria/2004/C-172-04.htm

Dutli, M. T. (2003). La protección de los niños en los conflictos armados, en particular la prohibición de la participación de los niños en las hostilidades y el régimen jurídico aplicable. Lecciones y Ensaios (78), 117-132.

Gallego, C. (2009). FARC-EP. Notas para una historia política. Bogotá, Colombia: Universidad Nacional de Colombia.

Guillén, C. A. (2006). Guerra o paz en Colombia. Cincuenta años de un conflicto sin solución. Bogotá, Colombia: Ocean Sur.

Hassan, V. (2013). Guerra irregular y Constitución: garantismo judicial de la Corte Constitucional Colombiana. Revista Mexicana de Derecho Constitucional (29), 245-284.

IACHR (2005). Inter-American Court of Human Rights. Case of the "Mapiripán Massacre" v. Colombia Judgment of September 15, 2005 Retrieved from http://www.corteidh.or.cr/docs/casos/ articulos/seriec_134_esp.pdf 
IACHR (2006). Inter-American Court of Human Rights Case of the Ituango Massacres v. Colombia Judgment of July 1, 2006. Retrieved from http:// www.corteidh.or.cr/docs/casos/articulos/ seriec_148_esp.pdf

Ibáñez Rivas, J. M. (2010). Los derechos de los niños, niñas y adolescentes en la jurisprudencia de la Corte Interamericana de Derechos Humanos. Revista IIDH, 51, 13-54.

Isa, F. (2014). Justicia, verdad y reparación en el proceso de paz en Colombia. Revista de Derecho del Estado (33), 35-63.

Martuscelli, P. N. (2006). O invisível caso do uso de crianças soldado na Colombia: implicações nas relações internacionais. Centro de Direito Internacional. Retrieved from http:// centrodireitointernacional.com.br/wp-content/uploads/2014/ 05/O- Invisi\%CC\%81velCaso-do-Uso-de-Crianc\%CC\%A7asSoldado-na-Colo\%CC\%82mbia-Implicac \%CC\%A7o\%CC\%83es-nasRelac\%CC\%A7०\%CC \%83es-Internacionais..docx

Peco Yuste, M. and Peral Fernández, L. (2005). El conflicto de Colombia. Madrid, España: Ministerio de Defensa.

Pinto, M. (1997). El principio pro homine. Criterios de hermenéutica y pautas para La regulación de los derechos humanos. In M. Abregu (Coord.), La aplicación de los tratados de derechos humanos por los tribunales locales (pp.163172). Buenos Aires, Argentina: Ediar, Centro de Estudios Legales y Sociales, Editorial del Puerto.
Trejos Rosero, L. F. (2013). Aproximaciones teórico-conceptuales en torno al conflicto armado colombiano. En C. Barreira, R. González Arana and L. F. Trejos Rosero (Eds.), Violencia política y conflictos sociales en América Latina (pp. 105-137). Barranquilla, Colombia, Buenos Aires, Argentina: Editorial Universidad del Norte; CLACSO. Retrieved from http://biblioteca. clacso.edu.ar/clacso/gt/20131113110812/ViolenciaPolitica.pdf

Unicef (1997). Cape Town Principles and Best Practices. Retrieved from https://www.unicef.org/ emerg/files/Cape_Town_Principles(1).pdf

United Nations (UN) (1989). The United Nations Convention on the Rights of the Child. Retrieved from https://downloads.unicef. org.uk/wp-content/uploads/2010/05/UN$\mathrm{CRC}_{\text {_ united_nations_convention }}$ on _the _rights _of the _ child.pdf? ga=2.72940947.1415577770.15519798061470067309.1551979806

United Nations (UN) (2014). Operational guide to the integrated disarmament, demobilization and reintegration standards. Recuperado de http://www. unddr.org/uploads/documents/Operational\%20Guide.pdf

Uribe de Hincapié, M. T. (1997). Antioquia: entre la guerra y la paz. Estudios Políticos (10), 126-137.

Valentine, S. (2003). Trafficking of Child Soldiers: Expanding the United Nations Convention on the Rights of the Child and its Optional Protocol on the Involvement of Children in Armed Conflict. New Eng. J. Int'l \& Comp. L., 9 (1), 109-134. 